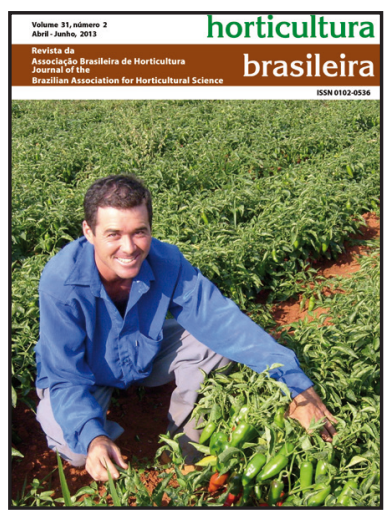

Campo da pimenta BRS Sarakura no Sul de Goiás. A cultivar, desenvolvida pela Embrapa, é destinada à produção de molho e apresenta alta produtividade e resistência a diversos patógenos. Foto: F. Reifschneider

\section{As hortaliças e o registro de agrotóxicos}

As hortaliças, devido ao seu cultivo intensivo, não sazonalizado, estão sujeitas a ataques de pragas, quer sejam fungos, insetos, ácaros, vírus e nematoides, durante todo o ano. Paradoxalmente, estas são culturas para as quais ou não há agrotóxicos registrados, ou há um número reduzido de registros. Consequentemente, falta suporte fitossanitário para um controle químico legalizado das pragas que as assolam. Segundo a Lei de Agrotóxicos - Lei 7802, de 11/07/1989 - somente agrotóxicos registrados podem ser utilizados, e o registro implica indicação obrigatória da cultura e da praga. Diante das obrigações legais a que estão sujeitas perante o registro de um agrotóxico, as empresas registrantes direcionam seus esforços para aquelas culturas que possibilitam melhor relação custo-benefício.

Os produtores de hortaliças queixam-se de que há poucas opções na grade de agrotóxicos registrados disponíveis para várias hortaliças como, por exemplo, pimentão, morango, melão, melancia e pimenta (que ilustra a nossa capa) entre outras. Os fabricantes de agrotóxicos alegam que os custos para o desenvolvimento de moléculas e os ensaios requeridos pelos órgãos federais envolvidos no registro de agrotóxicos -MAPA, Anvisa e Ibama são muito altos e exigem um retorno para o investimento que a área de cultivo de várias hortaliças não confere.

Assim, mesmo tendo à disposição no mercado agrotóxicos de alta tecnologia para controle químico de pragas que atingem suas lavouras, os produtores de hortaliças não podem utilizálos, pois as culturas hortícolas não são contempladas no rótulo e bula desses agrotóxicos. Sem alternativa para um controle químico eficiente, o produtor de hortaliças, ao optar por utilizar os agrotóxicos disponíveis no mercado, leva sua produção à ilegalidade. Ou seja, em toda a cadeia do agrotóxico, incluindo o receituário agronômico indicando que o agrotóxico será aplicado conforme as determinações do registro, tudo está na legalidade. A ilegalidade começa quando o agrotóxico é aplicado em cultura diversa da indicada no registro, o chamado desvio de uso. Neste caso, somente o produtor está na ilegalidade e, portanto, sujeito às penalidades previstas na Lei dos Agrotóxicos, que vão desde a advertência até pena de reclusão de dois a quatro anos.

Resultados de análises de resíduos feitas pela CEAGESP mostram a real situação da falta de registro de agrotóxicos para estas culturas. Do universo de hortaliças e frutas monitorado, $84,6 \%$ das amostras analisadas encontravam-se dentro da legalidade, sem resíduos de agrotóxicos $(69,4 \%)$ ou com detecção de resíduos legalmente aceita, isto é, abaixo do Limite Máximo de Resíduos (LMR) permitido $(15,2 \%)$. Das amostras fora da legalidade, $15 \%$ do total de amostras analisadas, apenas $1 \%$ apresentava resíduo do agrotóxico acima do LMR permitido, enquanto em outros $90 \%$ foram detectados resíduos de ingredientes ativos de agrotóxicos não registrados, às vezes, com teor de resíduo baixíssimo. Mas o fato de o produtor ter usado um agrotóxico não registrado para a cultura é suficiente para leválo, junto com a sua produção, à ilegalidade e para que a mídia promova as hortaliças a vilões da saúde pública.

Considerando a necessidade de trazer o controle fitossanitário praticado nas hortaliças para a legalidade, ampliando a oferta de ingredientes ativos registrados para o uso em culturas de menor expressão econômica (conhecidas mundialmente como minor crops), as áreas técnicas do MAPA, Anvisa e Ibama formaram um grupo de trabalho que teve por objetivo avaliar as experiências de outros países e, assim, desenvolver uma política de registro de agrotóxicos adequada a estas culturas no Brasil. Este trabalho resultou a Instrução Normativa Conjunta $\mathrm{n}^{\mathrm{o}} 01$, de 23/02/2010 (INC 01/2010).

A INC 01/2010 define estas culturas como "Culturas de Suporte Fitossanitário Insuficiente - CSFI" e cria agrupamentos de culturas nos moldes do Codex Alimentarius, levando em consideração ainda aspectos morfológicos das cultivares produzidas no Brasil, sua proximidade taxonômica, a semelhança de práticas agrícolas e a forma de consumo. Define regras e procedimentos para autorizar a extrapolação dos Limites Máximos de Resíduos LMR - de um ingrediente ativo registrado para uma cultura representativa do grupo para as demais culturas deste mesmo agrupamento, desde que respeitadas as indicações de alvos biológicos e dosagens previstas.

Três anos após a publicação da INC 01/2010 os avanços foram tímidos, evidenciando a necessidade de organização e capacitação dos interessados para que possam ser atendidas exigências da INC 01/2010. Os estudos de eficácia agronômica, toxicológicos e ecotoxicológicos são fundamentais para o registro de um agrotóxico e não podem ser dispensados. Por isso, o setor produtivo hortícola demandante de maior oferta de ingredientes ativos para as hortaliças - precisa passar a atuar como um agente ativo. O Poder Público, por força da Lei, atua como um agente intermediário no fluxo do processo de registro de um produto, em que a inclusão de uma cultura e de pragas a serem controladas nas recomendações do rótulo e bula são dependentes da anuência do registrante do agrotóxico.

Para que possamos avançar mais, um novo enfoque vem sendo proposto. Nele, o setor produtivo hortícola passaria a ter independência para apresentar estudos relativos aos princípios ativos que the interessam, deixando de ser apenas um agente de demanda, ao mesmo tempo em que os órgãos federais de registro poderiam autorizar o uso desses ingredientes ativos, independente da anuência do registrante.

A questão é claramente comercial. O custo de geração dos dados exigidos na legislação é alto. No entanto, esse custo pode ser diluído se a pesquisa pública assumir, ao menos parcialmente, esta responsabilidade, em parceria com o setor produtivo hortícola, contribuindo assim para a disponibilização de alimentos seguros para a população brasileira.

(Débora Cruz, Fiscal Federal Agropecuário do MAPA, debora.cruz@ agricultura.gov.br)

As ideias aqui expressas e as informações apresentadas são de responsabilidade do autor. 